\title{
Collective tradition meets individual creation: modern Nenets songs ${ }^{1}$
}

This presentation outlines some fundamentals of tradition and creation in modern Nenets songs - mainly from a structural perspective of melody and song text. This subject is a part of the author's ongoing work on the melodic and textual structures of the Nenets traditional songs.

Let it be stated in the beginning, that the mode and the principles of the acquisition of the material for this kind of study are far from unproblematic. The specific material here is limited - partially because of the fact that there are not so many composers and creators of modern songs among the Nenets. The main substance consists of recordings of the songs. I have had no opportunity to discuss these songs or the recordings with the performers themselves, except in one case (Susoi 1991). ${ }^{2}$ I have practically no means here to evaluate directly, how the performers themselves assess their recorded performances. Also the possibilities of indirect, comparative evaluation in the case of these songs are virtually nonexistent. The whole approach seems to be loaded with the problems of the old-fashioned "gather and analyze" -type of scientific understanding, that the modern paradigms in the cultural studies have long tried to get rid of.

However, the results and standpoints proposed are not based only on these three songs. During the last few years I have listened to, transcribed and analyzed approximately three hundred Nenets songs containing about two thousand text lines. With this kind of "indirect bimusical" experience, together with the specifically Nenets characteristics of verse formation (see below), there emerges an understanding about the structural logic of the melody and text. Furthermore, as a qualitative principle this means, that whatever the understanding is, it must be applicable to the whole material in some consistent way.

\footnotetext{
${ }^{1}$ I outlined the contents of this article at Laulasmaa, Estonia during the Finno-Ugric Folk Music Conference ("Folk Song and Folk Music as the Carrier of Identity and the Object of Cultural Change"), 18.10.1996.

${ }^{2}$ I have met, interviewed and recorded all these performers elsewhere, but the subjects talked and sung then had more to do with the traditional song culture.
} 


\section{The basic concepts}

Structural means, that the main analytical interest focuses here on the overall motif and segmentation structures in melody, on the metric system of the text and especially on the interaction between these two elements in a song. The basis for identification and interpretation of the structures themselves is their repetitive nature in an isometric framework (see below).

Modern refers to the urban, industrialized, Russian, European influence increasingly dominating in the cultural change of minorities.

Modern Nenets songs refers to music, composed or adapted more or less in the traditional Nenets song style, and enjoying nationwide popularity through the institutions of the modern urban culture (i.e., radio broadcasts, newspapers, concerts, records, printed music, music education). At the same time, however, this concept of modernity in Nenets songs involves distinctive stylistic features not to be found in traditional singing styles of the tundra dwellers.

Interestingly enough, the fact that this music is clearly conceptualized as composed and authored music, could be interpreted in both traditional and urban/modern senses. Firstly, the Nenets - like many other Northern peoples as well - have the traditional notion of authorship, ownership and copy and distribution rights of one's own songs (cf. Niemi 1992, 51-53). Secondly, the very concept of composer-ownership in this paper refers to the modern institution of composership or ownership of music.

\section{The artists-creators presented here}

Representatives of this modern Nenets music in this paper represent some of the most widely known Nenets artists: the writer and poet Lyubov' Prokop'yevna Nenyangg ${ }^{3}$ from the capital of the Taimyr Nenets autonomous region, Dudinka, singer-writer-composer Yelena Grigor'yevna Susoi and the composer Semyon Nikolayevich Nyarui, the last two both from the capital of the Yamal Nenets autonomous region, Salekhard.

Nenyangg ${ }^{4}$ is best known as a poet, novelist and journalist. Her work draws particularly on the traditional culture of the Taimyr Nenets. At the same time she is also known as singer-interpretator, composer and rearranger of the traditional Nenets songs. While having a song repertoire of various individual songs and

\footnotetext{
${ }^{3}$ In writing Nenets surnames, I have chosen to compromise between the name forms the people themselves are accustomed to use and the correct latinized transcription. If properly latinized, we should write: Nenets $\Rightarrow$ Nyenets; Nenyangg $\Rightarrow$ Nyenyangg; Salekhard $\Rightarrow$ Salyehard (Salyanggard!); Kanin $\Rightarrow$ Kanyin; Lapsui $=>$ Labtsui; Wèngga $\Rightarrow$ Wènngga.

${ }^{4}$ 15.11.1931-14.9.1996.
} 
sung fairy tales, she has composed some songs of her own whose texts are based on her poems.

Susoi's status includes not only composing, but specifically also performance. Apart from music, her contributions are connected mainly to education in the Nenets language. Her spouse, Leonid Vasil'yevich Lapsui was one of the best known Nenets poets, and he wrote the words to many popular songs of Nyarui.

One part of Susoi's song repertoire consists of traditional Nenets songs, which she has reworked and adapted according to her individual singing style. She has also specifically composed some songs to the words of Leonid Lapsui.

Nyarui is often mentioned as "the first Nenets composer" and therefore he has achieved a prominent position among the Nenets artists. Since Nyarui has a background of formal music education (St.Petersburg conservatory), he has gained the status of a more serious composer than Susoi. Nyarui is no longer the only one, since by now there are other artists having a conservatory education, like the singer Gennadi Lagei (Lèhè).

\section{Outlines of the verse system in Nenets songs}

All the songs discussed here - and a considerable part of the others too - have strong ties to the structures of the traditional songs. The metric organization of the text in particular shows strong uniformity.

Briefly outlined, the main feature in the metric organization of the Nenets song texts is its isometric nature, as explained by Khelimski (1989), and implied already by Hajdú (1978). Together with the music this means that in a song every text line is isosyllabic, of equal length (by the amount of the basic text syllables used). The melodic lines are also mostly isometric, but not necessarily. This principle is also reflected in the overall segmentation of a song: their consecutive line structure goes uniformly from the beginning to the end, not broken by inner divisions to line groups, verses or refrains. Rhyme is marginal and the correlation of the semantic of the text with the overall line structure is practically absent.

The key to understanding of the versification of the Nenets language is, of course, to know the prosodic means to transform the spoken language to sung language. Hajdú $(1978,356)$ already speaks about the differences between the "basic" and "sung" text of a song. So far, the researchers have had to analyze collected song texts, which have been dictated to the collector (biggest collections: Castrén-Lehtisalo 1940; Lehtisalo 1947; Kupriyanova 1965; Tereshchenko 1990) separately from an actual singing performance of that same song. This has resulted in a collection of basic texts, which are difficult as materials for metric studies, even if we knew how the basic text is transformed into a sung text.

The realization of the principle of isometricity in Nenets songs became possible only, when there emerged new insights about the phonology of the 
Nenets language. Janhunen's (1986) results especially concerning the analysis of the realization of the phonological deep level in Nenets help the metric analysis, even with basic texts (cf. Khelimski 1989, 224). In short, the notions concerning the phonological phenomena at the deep level of the Nenets language form the basis for understanding more exactly, how the spoken language ("basic text") is transformed into a sung language ("sung text"). It is out of the scope of this article to deal thoroughly with the different transformation rules, specified by Khelimski. Let it only be stated, that the metric features of the sung language are reflections from the phonological deep level of the language. After Khelimski there has been remarkable rethinking of Nenets phonology, especially by Salminen (e.g. 1993b). His results will be of great help in a closer understanding of the problems connected with transcription of the spoken language and its transformation into sung language.

The Nenets have two kinds of verse types: 1) a hexasyllabic "common" verse, and 2) a octosyllabic "shamanistic" verse. The hexasyllabic verse is used uniformly in all the other song genres, except shamanistic songs, which have the octosyllabic line structure. What could be the background of this kind of polarization of the verse types? Firstly, this kind of six-syllable verse type is restricted to the Northern Samoyeds (i.e., Nenets, Enets, Nganasan), while secondly, various eight syllable verse types can be found all over Southern Siberia (among the Turkic and Tungus peoples). Perhaps the eight-syllable verse - as well as shamanism as an institution - is historically a more recent element in the Nenets culture. This sounds quite logical, because the Samoyedic-speaking groups came to the Arctic zone from the Sayan mountain regions of the Southern Siberia (cf. Niemi 1992, 10-12).

The Nenets verse can be classified quite clearly as belonging to the syllabic verse types, as well as the versification of other Uralic languages. In these languages the word-stress is not so important a factor in versification of the language, as for example in Russian or English. While the main stress in Nenets falls to the first syllable, this particular notion requires thorough analysis of different possible word combinations in a line. The results from the analysis of Nenets songs - from the Kanin Peninsula to Taimyr - show striking uniformity and predominance of few word combinations in a line. Furthermore, these word combination types can be divided to two main categories, which have distinctive rhythmic manifestations on the level of the melodic line. Briefly, the first category consists of syllable groups organized on the principle even amount of wordforming syllables (i.e., SS+SSSS ${ }^{5}$; SS+SS+SS; SSSS+SS, etc., but also for example: $\mathrm{S}+\mathrm{S}+\mathrm{SSSS}$ ), while the second category is based on the principle of odd amount of syllable groups (SSS+SSS, S+SS+SSS, etc.). This issue is more thoroughly discussed in author's forthcoming doctoral dissertation.

${ }^{5} \mathrm{~S}=$ syllable. 
The possibilities for this kind of analysis have improved essentially during the 1990 's, so that the scarcity or lack of the suitable material - either linguistic or musical - is no longer a fundamental impediment. This situation has yielded remarkable rethinking not only in studies of Nenets phonology (cf. Salminen 1993a, 351-352; 1993b, 178), but also in musical analysis (cf. Niemi 1995).

\section{The songs}

The following examples are all modern Nenets songs, the verse types of which, however, are closely based on the traditional hexasyllabic verse. While the melodic features in these songs represent musical fusion with non-Nenets musical thinking, it is interesting to point out the traditional basis concealed in these modern songs.
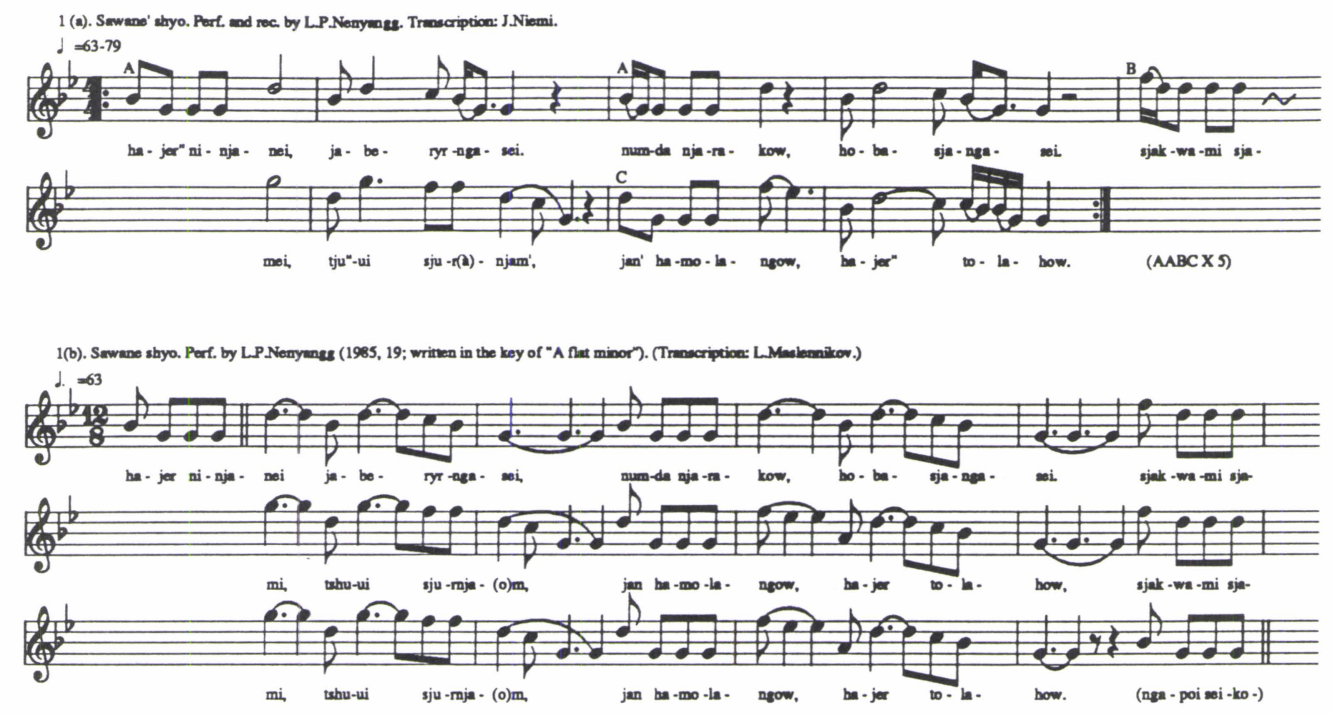

Example 1. Sawanye' shyo (Sawanye's song). Words and melody by Lyubov' Nenyangg. ${ }^{6}$

It is quite easy to see that the musical thinking involved in this melody (Example 1(a)-(b)) is closer to (urban) Russian than Nenets. Moreover, it belongs to the European world of functional harmony. Note that the published version (1(b), Nenyangg 1985, 19) has been transcribed in anacrustic triple rhythm, while this

${ }^{6}$ See the translations of the songs in the Appendices 2-4. 
was not so obvious after having heard Nenyangg's later performance of the song (1(a), where the time signature is only indicative) ${ }^{7}$ In my opinion however, both interpretations are acceptable.

I have chosen to represent the melody (here and elsewhere) in consistence with the representation of the isometric text lines, so that one bar always corresponds to one text line. Therefore, from the viewpoint of isometric representation of text and melodic lines, the anacrusis is practically absent in Nenets traditional songs. Anyhow, since the melody in Nenyangg's song is not traditional, it gives us an illustration of the applicability of the different musical styles, as well as their fusion.

If we try to trace the metric background of this kind of song (text), let it be only stated that the successful metric and poetic ${ }^{8}$ translation to Russian (Nenyangg 1989, 34-35) seems to have been quite an easy task. This is to say, that this type of textual thinking (as well as the melody) already reflects other than only traditional Nenets principles of constructing text lines.

At surface level, the song text can be interpreted as consisting of a quite consistent 5-syllable line (Table 1a). As such it would be misleading to try to interpret this system as such as traditional Nenets 6-syllable verse.

What is, however, interesting here, is that the verse system utilizes some basic line types or idioms, which could be expected in the Nenets traditional verse system. Therefore we could look more closely at the text, and especially at its hypothetical "traditional" basic form.

The key for the argumentation of this kind of experimentation is based on the results gained this far from the general analysis of word combination types in Nenets traditional songs (cf. App. 1). If we compare the distribution of the word combination groups in this experimentation and the other quantitative results, we notice that the overall figure is quite similar. The dominant word combination group is SS+SSSS, and the SSS+SSS group is also quite well represented. However, I shall not further analyze the text lines of the songs in this article in detail.

\footnotetext{
${ }^{7}$ All the transcriptions are written one octave higher from the original pitch.

${ }^{8}$ In the poetic translation the metrical feeling is considered more important than the exact translation of the original linguistical content.
} 


\begin{tabular}{|c|c|c|c|c|}
\hline ha - & jer" & $\mathrm{ni}-$ & nja - & nei, \\
\hline ja - & be - & ryr - & nga - & sei. \\
\hline num - & da & nja - & ra - & kow, \\
\hline ho-- & $\mathrm{ba}-$ & sja - & nga - & sei. \\
\hline sjak - & wa - & $\mathrm{mi}$ & sja - & mei, \\
\hline tshu - & "ui & sju - & $\mathrm{r}(\grave{a})-$ & njam', \\
\hline $\mathrm{Ca} 1$ & ha- & mo- & la - & ngow, \\
\hline ha- & jer" & to - & la - & how. \\
\hline nga - - & poi & sei - & ko(i) - & mei, \\
\hline tu-sj(à) — & da & $\mathrm{mja}-$ & $1(\mathrm{a})-$ & ha. \\
\hline waw - & $\mathrm{mi}$ & ha - & nju - & jei, \\
\hline ty - & nei" & jer - & w(à) - & sei". \\
\hline tshe-t(à) & njam - & dèi & jam - & bèim', \\
\hline po - & de-r(y) - & nga - & dam - & tshei. \\
\hline $\mathrm{Ca} 1$ & $\mathrm{pi}-$ & so - & $\mathrm{ta}-$ & nam', \\
\hline ha- & me - & $\mathrm{da}-$ & dam - & tshei. \\
\hline $\mathrm{Aa} 1$ & se - & hè - & rè - & ja', \\
\hline mjum - & nja & hè - & ri - & nga-d(à)m', \\
\hline tshe-t(à) & njam - & dèi & jam - & bèim', \\
\hline tja - & ha" & ha - & re - & nga-d(à)m'. \\
\hline sei - & $\mathrm{mi}$ & la - & ho - & ma, \\
\hline $\mathrm{ji}-$ & $\mathrm{mi}$ & pà — & ro - & ma. \\
\hline han - & $\mathrm{mi}$ & $\mathrm{me}-$ & re - & nga. \\
\hline mer - & tshja & hy - & no - & nga. \\
\hline ha- & $\operatorname{man}-$ & tshei & ty - & nei", \\
\hline njan-d(à) & $\mathrm{me}-$ & re" - & my - & jei? \\
\hline nja - & bi & ngè - & sy - & nèi, \\
\hline ngèw - & tortshj & hè —- & wè - & nèi... \\
\hline mer - & tsha & nen - & zja - & mja. \\
\hline num - & da & $\mathrm{pa}-$ & ri - & ma. \\
\hline ha- & jer". & jung - & $\mathrm{gu}-$ & ma. \\
\hline $\mathrm{ji}-$ & mei & $\mathrm{tab}-$ & to - & ma. \\
\hline wè - & wa & to-t $\mathrm{t}(\mathrm{y})-$ & $\mathrm{re}-$ & wèi', \\
\hline ho-b(à)" & pur - & kob - & $\mathrm{ta}-$ & tshe, \\
\hline ni-d(à)m' & nga - & tshe - & nang - & gu', \\
\hline ni-d(à)m' & ngam - & djo - & ring - & gu'. \\
\hline tsheb - & tèi & ja- & lja - & na, \\
\hline nga - & ni" & to - & ring - & gu-d(à)m', \\
\hline $\mathrm{pu}-$ & len-d(à)' & hè — & wa - & nèi, \\
\hline $\mathrm{pi}-$ & lei" & ngam - & dang - & guw'. \\
\hline 'Tèm-d(à)' & ha - & reng - & gu - & dèi', \\
\hline mja-t(à)' & je- & seng - & gu - & dèi', \\
\hline $\operatorname{sit}(\grave{a})^{\prime}$ & ju - & dang - & gu - & dèi', \\
\hline nju - & dad & hong - & $\mathrm{gu}-$ & dèi'. \\
\hline So - & o-k(à)m' & sè - & dang - & gu-d(à)m', \\
\hline pi - & bid & $\mathrm{pad}-$ & $\operatorname{tang}-$ & gudm'. \\
\hline $\mathrm{Nga}-$ & poi & py - & $\mathrm{da}-$ & rir", \\
\hline si" - & lim-t(à)" & mè - & neng - & gudm'. \\
\hline (nga - & ni". & niw' & nga" & ngèi,) \\
\hline (nga - & nei & $\operatorname{man}-$ & ty-(ni) - & wèi,) \\
\hline (ne- & nèi & hy - & no- & nga,) \\
\hline $\begin{array}{l}(\mathrm{njà}- \\
(52)\end{array}$ & $\mathrm{ra}$ & hy - & no - & nga.) \\
\hline
\end{tabular}

Table 1a. Text realized in performance of L. P. Nenyangg (1995a; 1995b). Transcribed by J. Niemi on the basis of the text transcription of L. P. Nenyangg (1995a). Syllables are presented in columns, which correspond graphically to the presentation of the rhythmic types (see Table 1d). The letters at the beginning of the row refer to the motif and line structure in the melody: an upper-case letter indicates the main motif division and a lower case letter its subdivision into two motifs. The purpose of marking the subdivision is to emphasize the existence of the isometric principle in modern songs too. A number following the letters correspond to the approximation of rhythmic types (see Table 1d). 


\begin{tabular}{|c|c|c|c|c|c|}
\hline Aal & ha - & jer" & $\mathrm{ni}-$ & nja - & nei, \\
\hline Aal & num - & da & nja - & $\mathrm{ra}-$ & kow, \\
\hline Bb3 & tshu - & "ui & sju - & $\mathrm{r}(\mathrm{a})-$ & njam', \\
\hline $\mathrm{Cb} 2$ & ha - & jer" & to - & la- & how. \\
\hline Aal & nga - & poi & sei - & ko(i) - & mei, \\
\hline Ab3 & tu-sj(à) - & da & $\mathrm{mja}-$ & $1(\grave{a})-$ & ha. \\
\hline Aal & waw - & $\mathrm{mi}$ & ha - & nju - & jei, \\
\hline $\mathrm{Ab} 2$ & ty - & nei" & jer - & w(à) - & sei". \\
\hline Ab2 & mjum - & nja & hè - & ri - & nga-d(à)m', \\
\hline $\mathrm{Ab} 2$ & $\mathrm{tja}-$ & ha" & ha - & re - & nga-d(à)m'. \\
\hline Ba1 & sei - & $\mathrm{mi}$ & la - & ho - & ma, \\
\hline $\mathrm{Bb} 2$ & $\mathrm{ji}-$ & $\mathrm{mi}$ & pà - & ro - & ma. \\
\hline $\mathrm{Ca} 1$ & han - & $\mathrm{mi}$ & me- & $\mathrm{re}-$ & nga. \\
\hline $\mathrm{Cb} 2$ & mer - & tshja & hy - & no- & nga. \\
\hline Aal & nja - & bi & ngè - & sy - & nèi, \\
\hline $\mathrm{Ab} 2$ & ngèw - & tortshj & hè - & wè - & nèi... \\
\hline Bal & mer- & tsha & nen - & zja - & mja. \\
\hline $\mathrm{Bb} 3$ & num - & da & $\mathrm{pa}-$ & ri - & ma. \\
\hline $\mathrm{Ca} 1$ & ha - & jer" & jung - & gu - & ma. \\
\hline $\mathrm{Cb} 2$ & $\mathrm{ji}-$ & mei & tab- & to - & ma. \\
\hline Aal & wè - & wa & to-t $(\mathrm{y})-$ & re - & wèi', \\
\hline $\mathrm{Ba} 1$ & tsheb - & tèi & ja - & lja - & na, \\
\hline Bb3 & nga - & ni" & to - & ring - & gu-d(à)m', \\
\hline $\mathrm{Ca} 1$ & $\mathrm{pu}-$ & len-d(à)' & hè - & wa- & nèi, \\
\hline $\mathrm{Cb} 2$ & $\mathrm{pi}-$ & lei" & ngam - & dang - & guw'. \\
\hline $\mathrm{Ab} 2$ & nju - & dad & hong - & gu - & dèi'. \\
\hline $\mathrm{Ba} 1$ & So - & o-k(à)m' & sè - & dang - & gu-d(à)m', \\
\hline Bb3 & $\mathrm{pi}-$ & bid & pad - & tang - & gudm'. \\
\hline $\mathrm{Ca} 1$ & Nga - & poi & py - & $\mathrm{da}-$ & rir" \\
\hline $\mathrm{Cb} 2$ & si" - & lim-t(à)" & mè - & neng - & gudm'. \\
\hline $\mathrm{Bb} 2$ & (nga - & nei & $\operatorname{man}-$ & ty-(ni) - & wèi,) \\
\hline $\mathrm{Ca} 1$ & (ne- - & nèi & hy - & no- & nga,) \\
\hline $\begin{array}{l}\mathrm{Cb} 2 \\
\text { (33) }\end{array}$ & (njà - & $\mathrm{ra}$ & hy - & no - & nga.) \\
\hline $\mathrm{Ab} 2$ & ja - & be - & ryr - & nga - & sei. \\
\hline $\mathrm{Ab} 2$ & ho - & ba - & sja - & nga - & sei. \\
\hline $\mathrm{Bb} 3$ & po - & de-r(y) - & nga - & dam - & tshei. \\
\hline $\begin{array}{l}\mathrm{Cb} 2 \\
\text { (4) }\end{array}$ & ha - & $\mathrm{me}-$ & $\mathrm{da}-$ & dam - & tshei. \\
\hline Bal & sjak - & wa - & $\mathrm{mi}$ & sja - & mei, \\
\hline $\begin{array}{l}\text { Aal } \\
\text { (2) }\end{array}$ & ha - & $\operatorname{man}-$ & tshei & ty - & nei", \\
\hline Ca1 & jan' & ha - & $\mathrm{mo}-$ & la - & ngow, \\
\hline $\mathrm{Ca} 1$ & noi & $\mathrm{pi}-$ & so - & ta - & nam', \\
\hline Aal & hoi' & se - & hè - & rè - & ja', \\
\hline $\mathrm{Ab} 2$ & njan-d(à) & $\mathrm{me}-$ & re" - & my - & jei? \\
\hline $\mathrm{Ab} 2$ & ho-b(à)" & pur - & kob - & $\mathrm{ta}-$ & tshe, \\
\hline $\mathrm{Aal}$ & ni-d(a) $m^{\prime}$ & nga - & tshe - & nang - & gu', \\
\hline $\mathrm{Ab} 2$ & ni-d(à)m' & ngam - & djo - & ring - & gu'. \\
\hline Aal & Tèm-d(à)' & ha - & reng - & $\mathrm{gu}-$ & dèi', \\
\hline $\mathrm{Ab} 2$ & mja-t(à)' & je - & seng - & gu - & dèi', \\
\hline Aa1 & si-t(à)' & ju - & dang - & gu - & dèi', \\
\hline Bal & tshe-t(à) & njam - & dèi & jam - & bèim', \\
\hline Aal & tshe-t(à) & njam - & dèi & jam - & bèim', \\
\hline $\begin{array}{l}\text { (2) } \\
\mathrm{Ba} 1\end{array}$ & (nga - & ni" & niw' & nga" & ngèi,) \\
\hline (1) & $(52)$ & & & & \\
\hline
\end{tabular}

Table 1b. Division of the lines according to the different word combination groups. 


\begin{tabular}{|c|c|c|c|c|c|c|}
\hline $\mathrm{Aa} 1$ & num - & $\mathrm{da}$ & nja - & $\mathrm{ra}-$ & ko - & w[à], \\
\hline $\mathrm{Bb} 3$ & tshu - & "ui & sju - & r(à) - & nja - & m[à]', \\
\hline $\mathrm{Ca} 1$ & ja - & $\mathrm{n}[\mathrm{a}]^{\prime}$ & ha- & mo- & la - & ngow, \\
\hline $\mathrm{Aa} 1$ & nga - & poi & se - & $\mathrm{j}[\mathrm{y}]-$ & ko(i) - & mei, \\
\hline $\mathrm{Ca} 1$ & no- & [j]i & $\mathrm{pi}-$ & so - & ta - & nam', \\
\hline Aal & ho- - & [j]i' & se - & hè - & rè - & ja', \\
\hline $\mathrm{Ab} 2$ & mjum - & nja & hè - & ri - & nga - & d(à) $\mathrm{m}^{\prime}$, \\
\hline $\mathrm{Ab} 2$ & tja - & ha" & ha- & $\mathrm{re}-$ & nga - & $\mathrm{d}(\mathrm{a}) \mathrm{m}^{\prime}$. \\
\hline $\mathrm{Ab} 2$ & njan - & $\mathrm{d}(\mathrm{a})$ & $\mathrm{me}-$ & re" - & my - & jei? \\
\hline $\mathrm{Aa} 1$ & wè - & wa & to - & $t(y)-$ & re- & wèi', \\
\hline $\mathrm{Ab} 2$ & ho- - & b(à)" & pur - & kob - & $\mathrm{ta}-$ & tshe, \\
\hline $\mathrm{Aa} 1$ & ni - & d(à)m' & nga - & tshe - & nang - & gu', \\
\hline $\mathrm{Ab} 2$ & $\mathrm{ni}-$ & $\mathrm{d}(\mathrm{a}) \mathrm{m}^{\prime}$ & ngam - & djo - & ring - & gu'. \\
\hline $\mathrm{Bb} 3$ & nga - & ni" & to - & ring - & gu - & d(à)m', \\
\hline $\mathrm{Cb} 2$ & $\mathrm{pi}-$ & lei" & ngam - & dang - & gu - & w[à]'. \\
\hline Aal & Tèm — & $\mathrm{d}(\mathrm{a})^{\prime}$ & ha- & reng - & gu - & dèi', \\
\hline $\mathrm{Ab} 2$ & $\mathrm{mja}-$ & $\mathrm{t}(\mathrm{a})^{\prime}$ & je - & seng - & gu - & dèi', \\
\hline $\mathrm{Aa} 1$ & $\mathrm{si}-$ & $\mathrm{t}(\mathrm{a})^{\prime}$ & ju - & dang - & gu - & dèi', \\
\hline Ba1 & So-o - & $\mathrm{k}(\mathrm{a}) \mathrm{m}^{\prime}$ & sè - & dang - & gu - & $\mathrm{d}(\grave{a}) \mathrm{m}^{\prime}$, \\
\hline $\mathrm{Bb} 3$ & $\mathrm{pi}-$ & bid & pad - & $\operatorname{tang}-$ & gu - & $\mathrm{d}[\mathrm{a}] \mathrm{m}^{\prime}$. \\
\hline $\mathrm{Ca} 1$ & $\mathrm{Nga}-$ & poi & py - & $\mathrm{da}-$ & ri- & r[à]]" \\
\hline $\mathrm{Cb} 2$ & $\mathrm{si}^{\prime \prime}$ - & lim-t(à)" & mè - & neng - & gu - & $\mathrm{d}[\mathrm{a}] \mathrm{m}^{\prime}$. \\
\hline $\begin{array}{l}\text { Bb2 } \\
\text { (23) }\end{array}$ & (nga - & nei & man - & ty - & (ni) - & wèi,) \\
\hline $\mathrm{Ba}$ & tshe - & $\mathrm{t}(\mathrm{a})$ & njam - & dèi & jam - & bèim', \\
\hline $\begin{array}{l}\text { Aal } \\
\text { (2) }\end{array}$ & tshe - & $\mathrm{t}(\mathrm{a})$ & njam - & dèi & jam - & bèim', \\
\hline $\begin{array}{l}\mathrm{Ba} 1 \\
\text { (1) }\end{array}$ & (nga - & ni" & $\mathrm{ni}-$ & w[à]' & nga" & ngèi,) \\
\hline $\begin{array}{l}\mathrm{Bb} 3 \\
\text { (1) }\end{array}$ & po - & $\mathrm{de}-$ & $r(y)-$ & nga - & dam - & tshei. \\
\hline $\begin{array}{l}\text { Bal } \\
\text { (1) }\end{array}$ & sja - & $\mathrm{k}[\mathrm{a}]$ - & wa - & $\mathrm{mi}$ & sja - & mei, \\
\hline Aal & ha - & $\mathrm{je}-$ & r[à]" & $\mathrm{ni}-$ & nja - & nei, \\
\hline $\mathrm{Cb} 2$ & ha - & je - & r[à]" & to - & la- & how. \\
\hline Ab3 & tu - & sj(à) - & $\mathrm{da}$ & $\mathrm{mja}-$ & $1(\grave{a})-$ & ha. \\
\hline Aal & wa - & w[à] - & $\mathrm{mi}$ & ha - & nju - & jei, \\
\hline $\mathrm{Ca} 1$ & ha - & n[à] - & $\mathrm{mi}$ & $\mathrm{me}-$ & re - & nga. \\
\hline $\mathrm{Ab} 2$ & ngèw - & tor - & tshj[à] & hè - & wè - & nèi... \\
\hline $\mathrm{Ca} 1$ & ha- & je - & r[à]" & jung - & gu - & ma. \\
\hline $\mathrm{Ca} 1$ & $\mathrm{pu}-$ & len - & $\mathrm{d}(\mathrm{a})^{\prime}$ & hè - & wa - & nèi, \\
\hline $\begin{array}{l}\mathrm{Ab} 2 \\
(9)\end{array}$ & nju - & $\mathrm{da}-$ & d[à] & hong - & $\mathrm{gu}-$ & dèi'. \\
\hline Ab2 & $\mathrm{ja}-$ & be - & ryr - & nga - & sei & [ngèi]. \\
\hline $\mathrm{Ab} 2$ & ho - & $\mathrm{ba}-$ & sja - & nga - & sei & [ngèi]. \\
\hline $\mathrm{Cb} 2$ & ha - & me - & $\mathrm{da}-$ & dam - & tshei & [ngèi]. \\
\hline $\begin{array}{l}\mathrm{Aa} 1 \\
\text { (4) }\end{array}$ & ha - & $\operatorname{man}-$ & tshei & ty - & nei" & [ngèi], \\
\hline Ab2 & ty - & nei" & jer - & w(à) - & sei" & [ngèi]. \\
\hline $\mathrm{Ba} 1$ & sei - & $\mathrm{mi}$ & la - & ho- & $\mathrm{ma}$ & [ngèi], \\
\hline $\mathrm{Bb} 2$ & $\mathrm{ji}-$ & $\mathrm{mi}$ & pà - & ro - & $\mathrm{ma}$ & [ngèi]. \\
\hline $\mathrm{Cb} 2$ & mer - & tshja & hy - & no- & nga & [ngèi]. \\
\hline Aal & nja - & bi & ngè - & sy - & nèi & [ngèi], \\
\hline $\mathrm{Ba} 1$ & mer - & tsha & nen - & zja - & mja & [ngèi]. \\
\hline $\mathrm{Bb} 3$ & num - & da & $\mathrm{pa}-$ & ri - & ma & [ngèi]. \\
\hline $\mathrm{Cb} 2$ & $\mathrm{ji}-$ & mei & tab - & to - & $\mathrm{ma}$ & [ngèi]. \\
\hline $\mathrm{Ba} 1$ & tsheb - & tèi & ja - & lja - & na & [ngèi], \\
\hline $\mathrm{Ca} 1$ & (ne - & nèi & hy - & no- & nga & [ngèi],) \\
\hline $\begin{array}{l}\mathrm{Cb} 2 \\
(11)\end{array}$ & (njà - & ra & hy - & no - & nga & $\begin{array}{l}\text { [ngèi].) } \\
(52)\end{array}$ \\
\hline
\end{tabular}

Table 1c. Division of the lines according to the different word combination groups as a hypothetical reconstruction of the text lines into six-syllable-lines. 


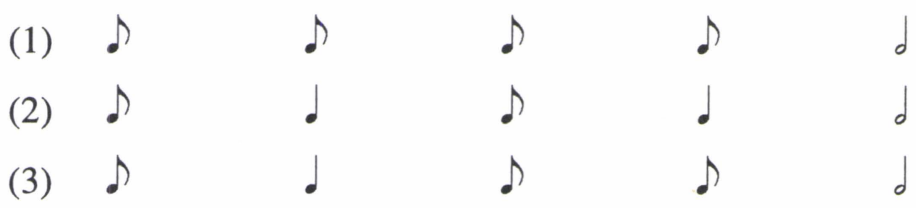

Table 1d. Approximation of the types of rhythmic manifestations.

The preceding table (Table 1c) is a hypothetical reconstruction of the text lines. It is based on the expected appearance of the deep level syllables. The occurrence of a deep level syllable is indicated by a letter in square brackets [à, è, y, $\left.j^{9}\right]$. The use of different letters is for approximating the phonetic qualities expected, according to the rules of vowel harmony in Nenets. Square brackets are also used to mark the possible supplementary syllables, e.g. [ngèi], that could be expected at the end of some lines.

It must be noted that some of the reduced vowel phenomena are actually heard in the performance. These incidents are written in parentheses ( ) (Table $1 b-c)$.

Susoi's song (example 2) represents more clearly the traditional Nenets musical thinking. Firstly, the two-line melodic structure has a fairly characteristic upward leap at the beginning of the melodic line A. ${ }^{10}$ Furthermore, the echoed repeat of the end of the melodic line is a possible, although perhaps more seldom used feature in Nenets songs. For the sake of comparison, I have presented two recorded versions of the song. Although the 1991 version is only a fragment, it shows clearly, that the fundamental melodic features are quite close to each other, which is not necessarily the case with different performances of traditional songs in general.

\footnotetext{
${ }^{9}$ I have left the Nenets passages in their original form, resulting in some differences as to their English pronunciation.: "y"= middle-i, "j"= y (indicating palatalization of preceding consonant); "tsh"=ch. The accent on a vowel indicates reduction (in the case of "è" it means also, that the preceding consonant is non-palatalized).

10 Note, that the slurs used here always indicate strong continuity in grouping of notes and the corresponding pitch changes. Furthermore, the groups are always marked with one slur, which corresponds to the text syllable. I also use occasionally a straight line symbol to specially emphasize the glissando effect.
} 
2(a). Syihirtya nye nyu. (Perf. by Yelena Grigoryevna Susoi, Melodiya S90 27639003 / B2. Transcription: J.Niemi. d $=108$

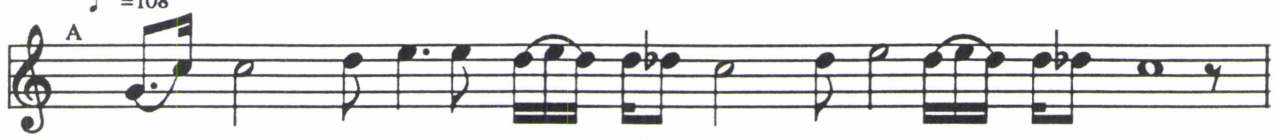

sa - ljow - (ho - ho - w(à)) ja - d(a)-ha - now (hè - hèi) ja - d(a)-ha - now,

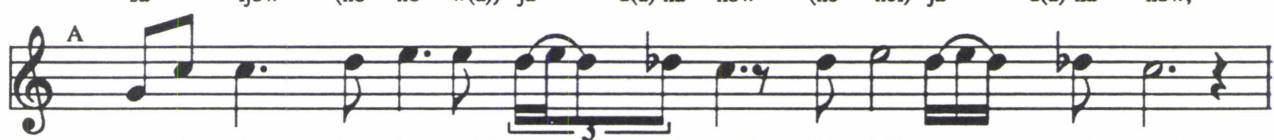

si - hir - tjow - (ho- ho- w(à)) ne nju - ngèi (hè - hèi) ne nju - ngèi,

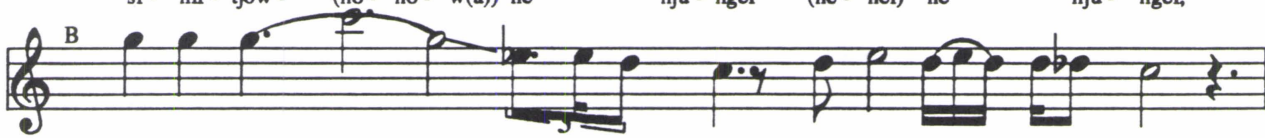

sju - ri- dow wym-da - nga - (ngèi) (hè - hèi) wym - da -nga - (ngèi).

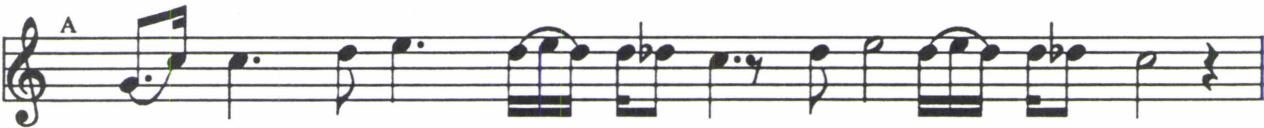
sja -
(hè - hèi)
ja -
$r(\mathbf{a})$-pa - nèi
(hè - hèi) ja -
r(a)-pa - nèi,

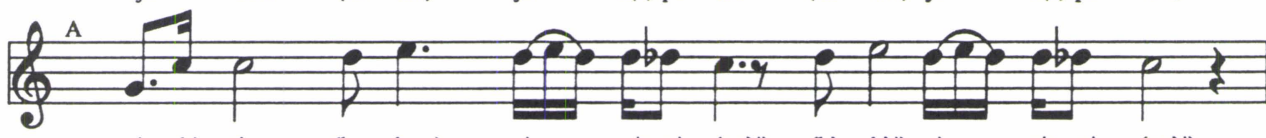

si - hir - tjow - (ho - how) ni - sja-mi - (ngèi) (hè - hèi) ni - sja- mi - (ngèi),

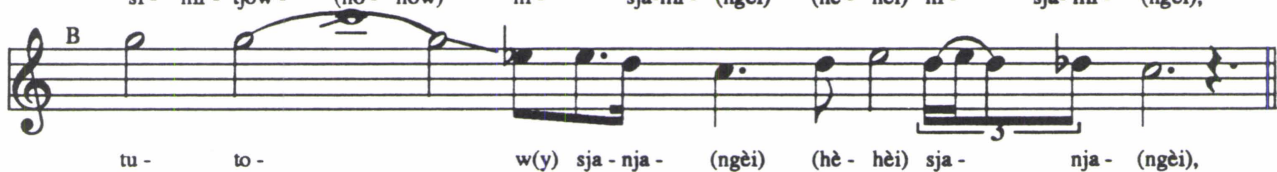

(AAB AAB)

2(b). Syihirtya nye nyu. (Perf. by Yelena Grigoryevna Susoi, rec. by J.Niemi, Tampere 7/1991. Transcription: J.Niemi.
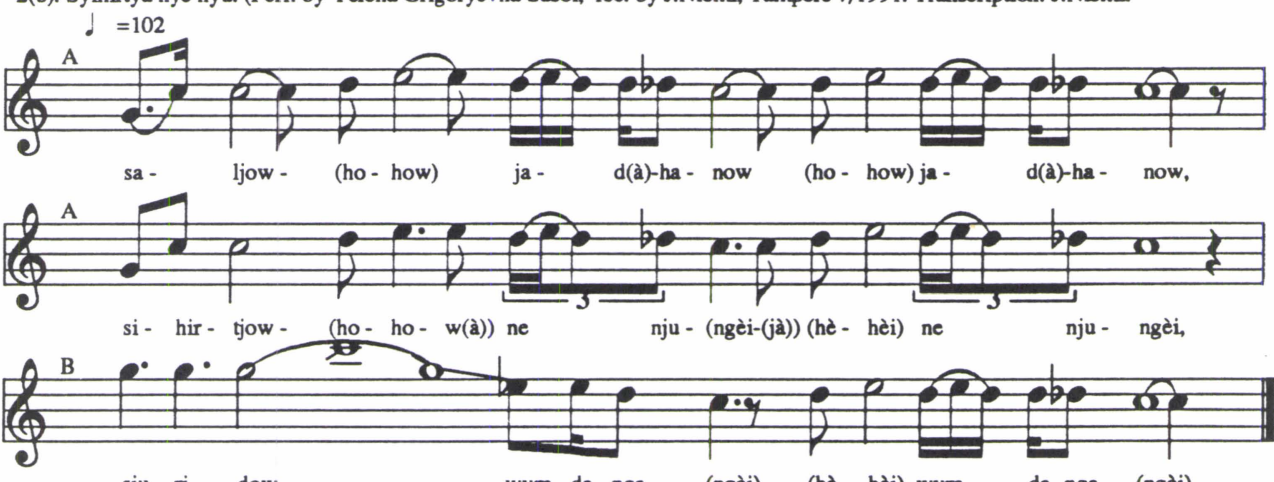

sju - ri - dow

wym - da - nga -

(ngèi)

(hè - hèi) wym -

da -nga - (ngèi).

Example 2. Syikhirtya' nye nyu (Syikhirtya-girl). Original poem by Ivan Yuganpelik, melody and arrangement by Yelena Grigor'yevna Susoi. 
What is peculiar here is the B-line, which the author has deliberately attached to the melodic structure to represent "the howling of the tundra wind". ${ }^{11}$ This kind of melodic expression with its stepless descending is rather a feature of Susoi's personal artistic and staged expression, than a traditional one.

Despite this, the overall text line structure is strongly traditional, although this short song also contains many discrepancies from the "ideal" text line forms. This is actually a good example to illustrate, that although the Nenets songs can be argued to have some fundamental uniformities on the levels of melody and especially text, I am not by any means arguing that deviations from the "norm" do not exist.

The opposition of the rhythmic manifestations, caused by the main division of the word combination groups $(2+2+2$ and $3+3)$ can be seen here quite clearly (Table $2 \mathrm{~b}$ ). While both of the main word combination groups have a specific rhythmic manifestation, the supplementary syllable (ngèi) can function as filling the metrical space especially in the $3+3$-group. Therefore the line belonging to the 3+3-group can be interpreted as consisting of five proper syllables + one supplementary syllable, or six proper syllables + one supplementary (cf. 2nd line vs. 5th line in Table 2a).

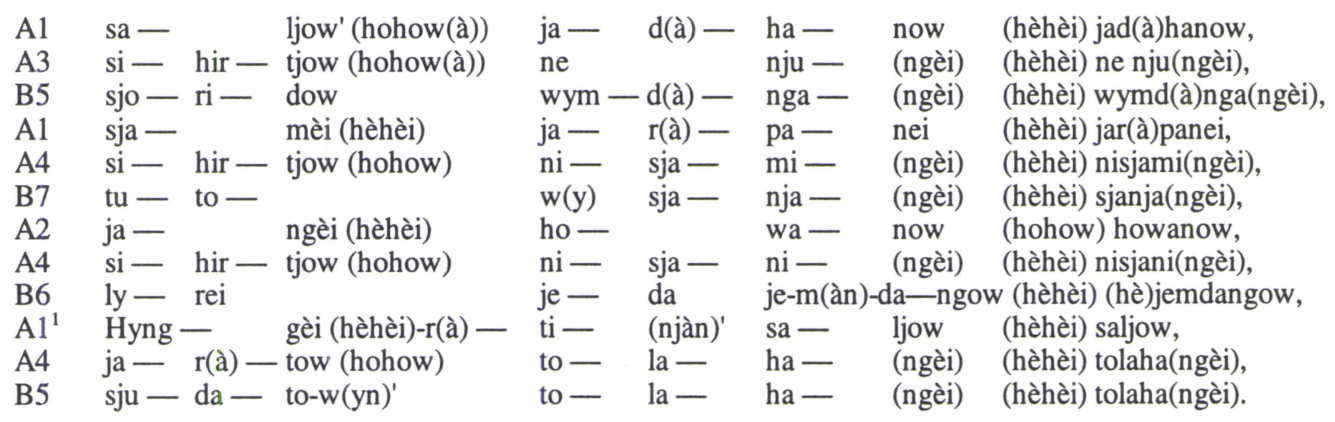

Text realized in performance of J.G.Susoi (1991).
A3 sa - ljow' (hohow(à))
B5 sjo- ri- dow
$\begin{array}{ll}\text { ja }-\mathrm{d}(\mathrm{a})- & \text { ha }- \\ \text { ne } & \text { nju }- \\ \text { wym }-\mathrm{d}(\mathrm{a})- & \text { nga }-\end{array}$
now (hèhèi) jad(à)hanow,
(ngèi) (hèhèi) ne nju(ngèi),
(ngèi) (hèhèi) wymd(à)nga(ngèi).

Table 2a. Text realized in performance of Ye.G. Susoi (1988). Division of syllables into columns correspond graphically to the representation of the rhythmic types (see Table 2c). The capital letter refers here to the isometric line containing the six-syllable text line with its supplementions and echoings. The following number refers to the type of the rhythmic manifestation of the line (see Table $2 b$ ).

\footnotetext{
${ }^{11}$ As stated by the author of the song herself.
} 


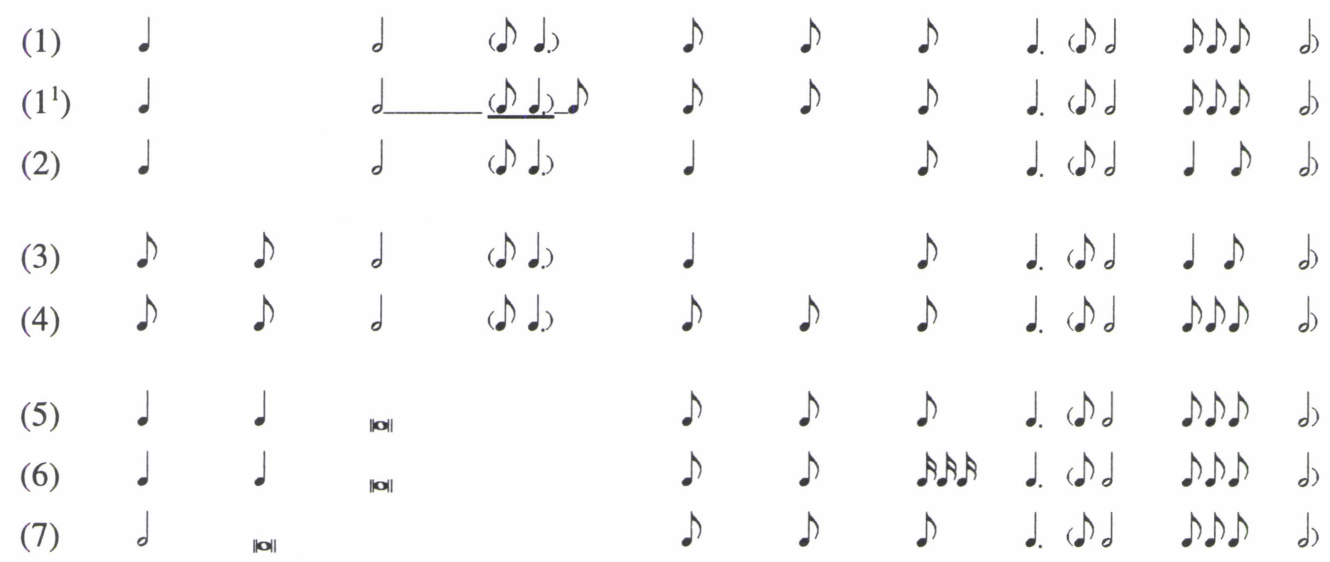

Table 2b. Approximation of the types of rhythmic manifestations. Supplementary and echoed text elements are put into parentheses. The types are ordered into groups according to the word combination grouping: types 1-2 correspond to the $2+2+2$-group, types 3-4 to the 3+3-group and types 5-7 to the exceptional groups.
A1 sa - ljow'
ja -
d(à) -
ha -
now,
A1 sja - nèi
ja -
r(à) -
pa -
nei,
(2)
$A 1^{1}$ Hyng - gèi-r(à) -
ti — $\quad$ (njàn) ${ }^{\prime}$
sa -
ljow,
(1)
B5 sjo -
ri -
wym - d(à) -
nga -
(ngèi),
A4 si- hir - tjow
$\mathrm{ni}-\quad \mathrm{sja}-$
$\mathrm{mi}-$
(ngèi),
A4 si-
hir - tjow
ni- sja -
$\mathrm{ni}-$
(ngèi),
A4 ja-
$\mathrm{r}(\mathrm{a})$ -
tow
to - la -
ha -
(ngèi),
B5 sju -
da -
to-w(yn)
to - la -
ha -
(ngèi).
A3 si -
hir -
tjow
ne
nju - (ngèi),
B7
to -
$\mathrm{w}(\mathrm{y})$
sja -
nja -
(ngèi),
A2 ja-
ngèi
ho -
wa -
now,
(1)
B6 ly -
rei
je -
da
je-m(àn)-da -
ngow,

(Susoi 1991).
A1 sa - ljow'
ja -
d(à) -
ha -
now,
(1)
A3 si -
hir -
tjow
ne
nju -
(ngèi),
B5 sjo -
ri -
dow
wym - d(à) -
nga -

Table 2c. Division of the text lines according to the different word combination groups (Susoi 1988). 
3. Wy jana' sjojo ("The Song of the Tundra".) by Semyon Nikolayevich Nyarui. Perf. (piano \& vocal) by S.N. Nyarui. Transcription: J.Niemi.

Recording copied from the original tape JA-60 of the phonourchive of the Yamal Nenets Committee
of the District Radio and Televison Broedcasting, Yamal Nenets Autonomous District, Salekhard.

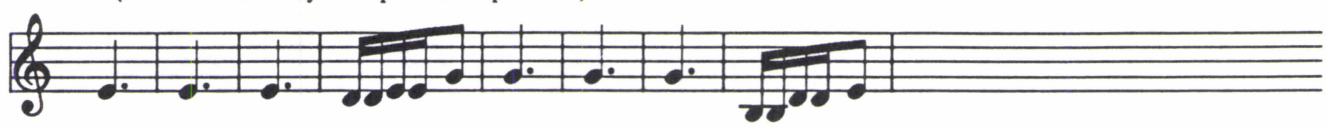

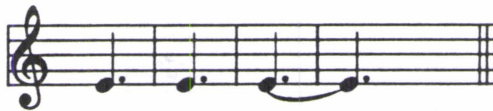

B

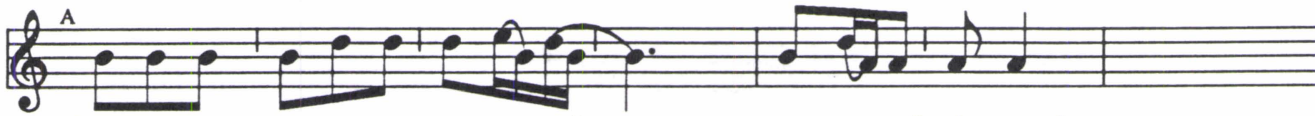

1.

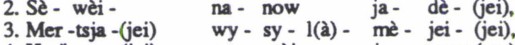

4. Har" -na-(jei) wyng-gèi ja- wow-(ow),

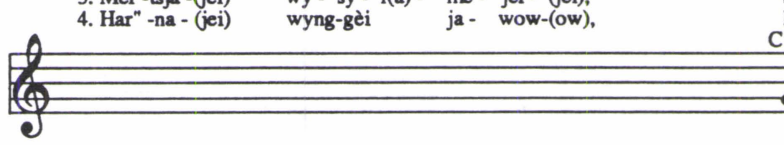

....................? ja - wow"

sjo ha- na- ba - now",

hy - no" - la - nga - wow",
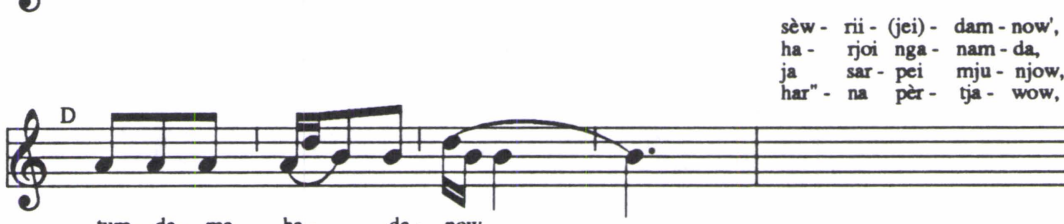

$\begin{array}{lll}\text { tum - da - ma ha- } & \text { da- now, } \\ \text { ji - la- ri- bè- } & \text { nan- dow, }\end{array}$

ji- la - da- ljo- bèi- na- now,

sa- wa- li - sei - ty - wow".

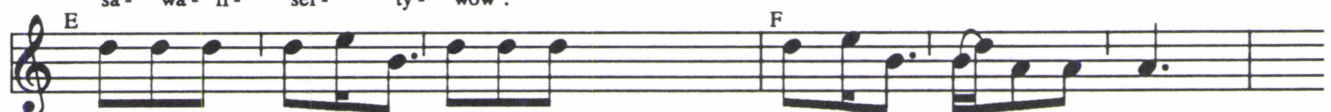

tju - ku- (jei) mè - ta - (jei) sjo- wow,

tir - tjà - (jei) sar - mei - kè - tsè - (jei),

wyng-gè - (jei) sè - hè - rè - mèi,

Par- ti- ja- na" ne - da,

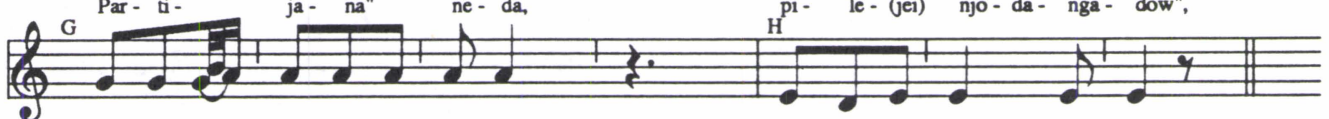

$\begin{array}{ll}\text { ner - te - (jei) } & \text { sjo- wa - na - tow, } \\ \text { (o) - ho- } & \text { re - ko- da - re - wèi, } \\ \text { ji - rei- } & \text { na - nèi sjo- jow, } \\ \text { ja- lèim- } & \text { da - dèi num - gy - (jei), }\end{array}$

$\begin{array}{lll}\text { hy - nob - tam - ba - } & \text { nga - } & \text { wow. } \\ \text { te - lè - wè - ko- } & \text { ra - ha } \\ \text { har" - na we - ta - } & \text { bi - wow". }\end{array}$

har" - na wè - ta - bi - wow".

ngu - don - do - ne -

nga - dow"

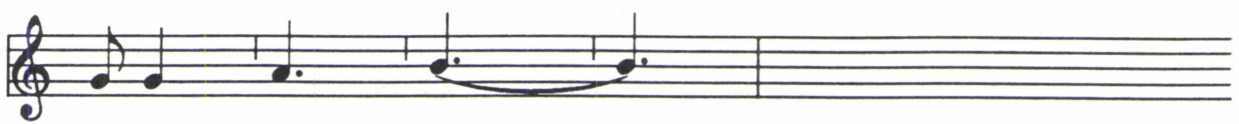

Hèi hèi hèi, hèi,

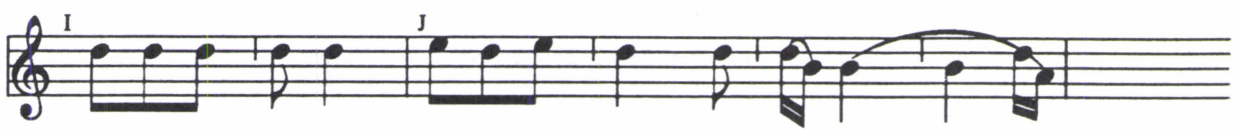

wy ja- na' ho- jow, ji- leb-tsi- (jei) nga- wow-(ow)', 


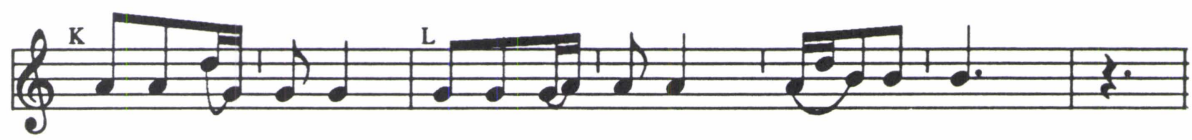

wy ja- na' sjon-zja, sa- wa jil- je-(jei) lat - ro- how,
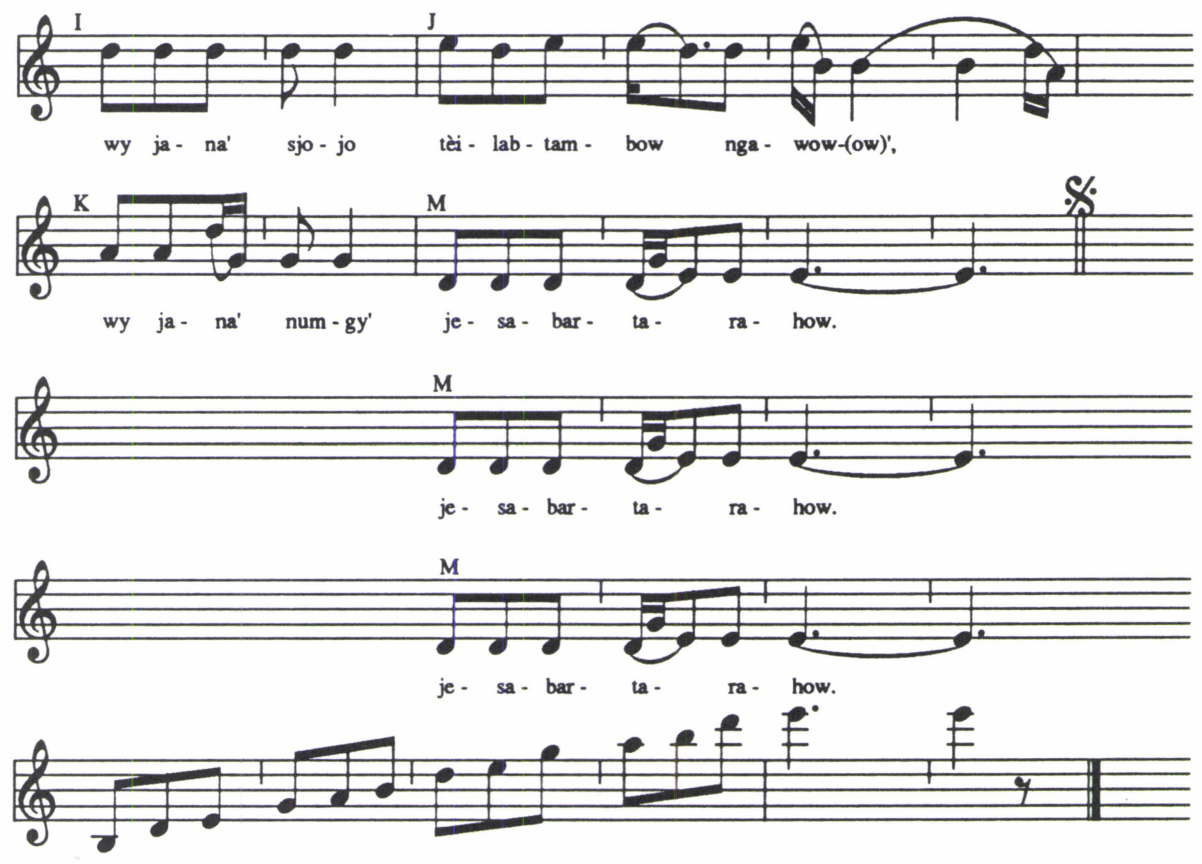

Example 3. Wy' yana" syo (The song of the tundra). By Semyon Nikolayevich Nyarui.

This song is a characteristic example of Susoi's artistic expression, in which individual musical creation lives organically within the basis of tradition. However, the elements of fusion are different than in Nenyangg's song. While Nenyangg has chosen Russian musical thinking to back up her text, Susoi tends to emphasize Nenets musical thinking in her songs. In this case, the emphasis is created with folkloristic dramatization of songs. As Susoi herself explains, it is her task to recreate Nenets traditional songs specially for staged performances (Susoi 1991). This dramatization is realized by "acting" the song with bodily gestures depicting the text content.

The last example song differs remarkably from the preceding ones. Nyarui's way of composing with a musical instrument (piano or accordion) yields a totally different kind of music. Separate melodic motifs have traditional flavor, but the overall structure is more complex than in traditional songs. Melodic and rhythmic features are more solid, due to the musical thinking and performing with a musical instrument involved.

At melodic level, this song is yet another kind of example of transformation 
of musical thinking. The traditional Nenets melodic thinking is based on undulation of a few tones in a way where a melodic leap itself is more important than its size and stability. Hungarian ethnomusicologist Katalin Lázár $(1996,156)$ has ended up with similar notions when studying Eastern Khanty songs. However, Nyarui has transformed and fixed this thinking on the keyboard of the piano, resulting in a larger anhemitonic scale type (see the concluding instrumental passage), to which features of functional harmony can be applied.

I have presented the note transcription in line paradigms, so that some recurring elements can be more clearly discerned. At the same time, however, it must be emphasized that this kind of paradigmatic presentation is best applied in the traditional songs, not so much here, due to the complexity of the compositional structure. Moreover the division of melodic motifs according to their corresponding to the text lines does not illustrate the overall structure here as effectively as in the traditional songs (see, e.g., the overlapping of the melodic motifs with the text lines during the melodic motifs $\mathrm{E}$ and $\mathrm{F}$ ).

All these elements together reveal Nyarui's playful mastery and skill in composing new music based on tradition. As we can clearly see, the text lines already look quite familiar. It is not only that the six-syllable lines are dominant here too but special attention should be paid to the way Nyarui has composed the melodic lines so that the sung syllables (in parentheses, if articulated separately; otherwise here in the form of -ow or -èi) at the end of words are placed most naturally, according to the meter of the text. This is especially evident with the $2+2+2$-word combination group (see Table $3 b){ }^{12}$

\footnotetext{
${ }^{12}$ Nyarui uses many sung syllables, possibly more than in traditional songs in general. This is due to his energetic performance style, and particularly in this song, due to the compositional structure. $\mathrm{He}$ also tends here to articulate many sung syllables separately. For example, in a song, the word wynggy (pertaining to tundra) would "normally" be transformed as wynggèi, but Nyarui multiplies it as wynggè(jei).
} 


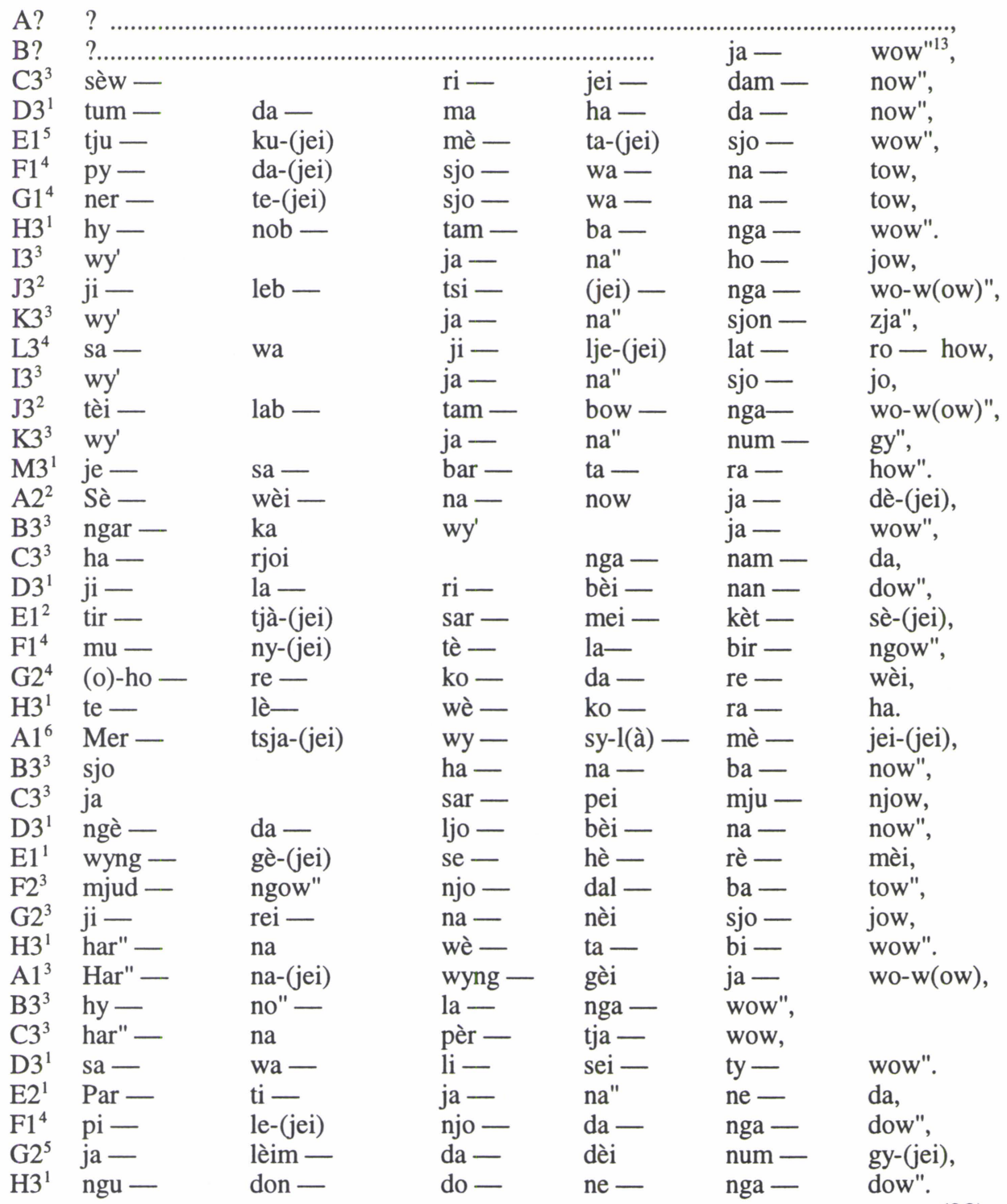

Table 3a. Text realized in performance of S. N. Nyarui (198?). Transcribed by J. Niemi on the basis of the text transcription of M. Ya. Barmich. Here the syllable columns do not correspond graphically to the representation of the rhythmic types.

\footnotetext{
${ }^{13}$ The initial instrumental passage and two first text lines at the beginning of the song are not heard, due to damaged original tape (!).
} 


\begin{tabular}{|c|c|c|c|c|c|c|}
\hline $\mathrm{F} 1^{4}$ & py - & da-(jei) & sjo - & wa - & na - & tow, \\
\hline $\mathrm{G} 1^{4}$ & ner - & te-(jei) & sjo - & wa - & na - & tow, \\
\hline $\mathrm{E} 1^{2}$ & $\operatorname{tir}-$ & tjà-(jei) & sar - & mei - & kèt - & sè-(jei), \\
\hline $\mathrm{F} 1^{4}$ & $\mathrm{mu}-$ & ny-(jei) & tè - & la- & bir - & ngow", \\
\hline $\mathrm{A} 1^{6}$ & Mer - & tsja-(jei) & wy - & sy-l(à) - & mè - & jei-(jei), \\
\hline $\mathrm{E} 1^{1}$ & wyng — & gè̀-(jei) & se - & hè - & rè — & mèi, \\
\hline $\mathrm{F}^{3}{ }^{3}$ & mjud - & ngow" & njo - & dal - & ba - & tow", \\
\hline $\mathrm{H} 3^{1}$ & har" — & na & wè - & $\mathrm{ta}-$ & bi - & wow". \\
\hline $\begin{array}{l}\mathrm{F} 1^{4} \\
(9)\end{array}$ & $\mathrm{pi}-$ & le-(jei) & njo - & $\mathrm{da}-$ & nga - & dow", \\
\hline $\mathrm{H} 3^{1}$ & hy - & nob - & $\operatorname{tam}-$ & $\mathrm{ba}-$ & nga - & wow". \\
\hline $\mathrm{J}^{2}$ & $\mathrm{ji}-$ & leb - & tsi - & (jei) - & nga - & wo-w(ow)", \\
\hline $\mathrm{J}^{2}{ }^{2}$ & tèi - & lab - & $\operatorname{tam}-$ & bow - & nga- & wo-w(ow)", \\
\hline $\mathrm{M}^{1}{ }^{1}$ & je - & $\mathrm{sa}-$ & bar - & $\mathrm{ta}-$ & $\mathrm{ra}-$ & how". \\
\hline D3 ${ }^{1}$ & $\mathrm{ji}-$ & la - & $\mathrm{ri}-$ & bèi - & nan - & dow", \\
\hline $\mathrm{G} 2^{4}$ & (o)-ho - & re - & ko - & $\mathrm{da}-$ & re - & wèi, \\
\hline $\mathrm{H} 3^{1}$ & te - & lè- & wè - & ko - & $\mathrm{ra}-$ & ha. \\
\hline D3 ${ }^{1}$ & ngè - & $\mathrm{da}-$ & ljo - & bèi - & na - & now", \\
\hline D3 ${ }^{1}$ & $\mathrm{sa}-$ & wa - & li - & sei - & ty - & wow". \\
\hline $\begin{array}{l}\mathrm{H}^{1}{ }^{1} \\
(10)\end{array}$ & ngu - & don - & do - & ne - & nga - & dow". \\
\hline $\mathrm{A} 2^{2}$ & Sè - & wèi - & na - & now & $\mathrm{ja}-$ & dè-(jei), \\
\hline $\mathrm{G} 2^{3}$ & $\mathrm{ji}-$ & rei - & na - & nèi & sjo - & jow, \\
\hline $\mathrm{E} 2^{1}$ & Par - & $\mathrm{ti}-$ & ja - & na" & ne - & \\
\hline $\begin{array}{l}\mathrm{G} 2^{5} \\
(4)\end{array}$ & $\mathrm{ja}-$ & lèim - & $\mathrm{da}-$ & dèi & num - & gy-(jei), \\
\hline $\mathrm{E} 1^{5}$ & tju - & ku-(jei) & mè - & ta-(jei) & sjo - & wow", \\
\hline $\begin{array}{l}\mathrm{A} 1^{3} \\
(2)\end{array}$ & Har" — & na-(jei) & wyng - & gèi & $\mathrm{ja}-$ & wo-w(ow), \\
\hline $\begin{array}{l}\mathrm{D} 3^{1} \\
\text { (1) }\end{array}$ & tum - & $\mathrm{da}-$ & $\mathrm{ma}$ & ha - & $\mathrm{da}-$ & now", \\
\hline $13^{3}$ & wy' & & ja - & na" & ho - & jow, \\
\hline $\mathrm{K} 3^{3}$ & wy' & & $\mathrm{ja}-$ & na" & sjon - & zja", \\
\hline $\mathrm{I}^{3}$ & wy' & & $\mathrm{ja}-$ & na" & sjo - & jo, \\
\hline $\begin{array}{l}\mathrm{K}^{3}{ }^{3} \\
(4)\end{array}$ & wy' & & $\mathrm{ja}-$ & na" & num - & gy", \\
\hline $\begin{array}{l}\mathrm{B}^{3} \\
\text { (1) }\end{array}$ & sjo & & ha - & na - & $\mathrm{ba}-$ & now", \\
\hline $\begin{array}{l}\mathrm{C} 3^{3} \\
(1)\end{array}$ & $\mathrm{ja}$ & & sar - & pei & mju - & njow, \\
\hline $\begin{array}{l}\mathrm{B}^{3} \\
(1)\end{array}$ & ngar - & ka & wy' & & $\mathrm{ja}-$ & wow", \\
\hline $\mathrm{C} 3^{3}$ & ha - & rjoi & & nga - & nam - & da, \\
\hline $\begin{array}{l}\mathrm{C} 3^{3} \\
(2)\end{array}$ & har" - & na & pèr - & tja - & wow, & \\
\hline$C 3^{3}$ & sèw - & & $\mathrm{ri}-$ & jei - & dam - & now", \\
\hline $\begin{array}{l}\mathrm{B}^{3} \\
(2)\end{array}$ & hy - & no" - & la - & nga - & wow", & \\
\hline $\begin{array}{l}\mathrm{L}^{4} \\
(1)\end{array}$ & sa - & wa & $\mathrm{ji}-$ & lje-(jei) & lat - & $\begin{array}{r}\text { ro - how, } \\
(38)\end{array}$ \\
\hline
\end{tabular}

Table 3b. Division of the text lines according to the different word combination groups (Nyarui 198?). 

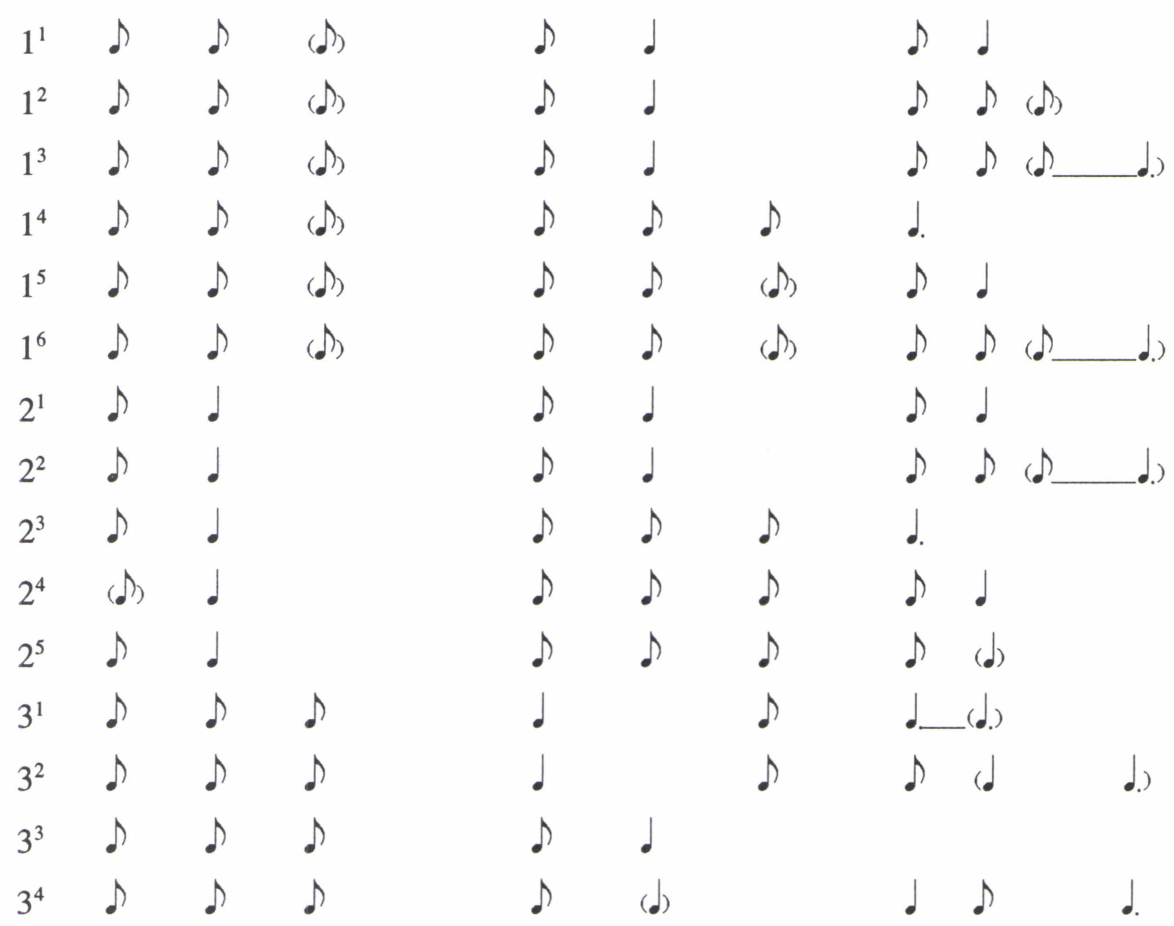

Table 3c. Approximation of the types of rhythmic manifestations.

Finally, the rhythmic types have a certain correlation to the word combination groups of the text lines (see Table 3b). Here, for example, the SS+SSSS- and the SS+SS+SS-groups are manifested mostly through the rhythm type 1 , the SSSSSS-group and the five-syllable lines through type 3 and SSSS+SS-group through type 2 . In this case, though, it can be argued that this is possibly more due to intentionally planned composition, than "natural" laws of the Nenets verse.

\section{Sources}

\section{Literal sources:}

Castrén, Matthias - Lehtisalo, Toivo 1940. Samojedische Volksdichtung. MSFOu 82. Helsinki : Suomalais-ugrilainen seura.

Dobrovol'ski, Boris 1965. O napevakh nenetskikh epicheskikh pesen. Epicheskiye pesni nentsev. Moskva : Nauka.

Hajdú, Péter 1978. The Nenets Shaman Song and its Text. Shamanism in Siberia. Budapest. 
Janhunen, Juha 1986. The Glottal Stop in Nenets. MSFOu 196. Helsinki : Suomalais-ugrilainen seura.

Khelimski, Eugen 1989. Glubinno-fonologicheski izosillabizm nenetskogo stikha. JSFOu 82. Helsinki : Suomalais-ugrilainen seura.

Khomich, Lyudmila 1966. Nentsy. Moskva-Leningrad : Nauka.

Kupriyanova, Zinaida 1965. Epicheskiye pesni nentsev. Moskva : Nauka.

Lázár, Katalin 1996. A keleti hantik vokális népzenéje. Budapest.

Lehtisalo, Toivo 1947. Juraksamojedische Volksdichtung. MSFOu 90. Helsinki : Suomalais-ugrilainen seura.

Nenyangg, Lyubov' 1985. Nenetskiye pesni. (Ed. by L.Maslennikov.)

Krasnoyarsk : Krasnoyarskoye knizhnoye izdatel'stvo.

Nenyangg, Lyubov' 1989. Raduga: Stikhi. Krasnoyarsk : Krasnoyarskoye knizhnoye izdatel'stvo.

Nenyangg, Lyubov' 1995a. "Pesni nentsev Taimyra". Manuscript.

Niemi, Jarkko 1992. Nenetsien musiikkikulttuuri: laulut ja soittimet. Licentiate thesis. Tampere University. (Unprinted.)

Niemi, Jarkko 1995. Transcriptions of Nenets Songs in A.O.Väisänen's

"Samojedische Melodien" Re-evaluated. JSFOu 86. Helsinki : Suomalaisugrilainen seura.

Salminen, Tapani 1993a. A Phonemization of Tundra Nenets Long Vowels. Hajdú Péter 70 Éves. Budapest.

Salminen, Tapani 1993b. On Identifying Basic Vowel Distinctions in Tundra

Nenets. Finnisch-Ugrischen Forschungen 51. Helsinki : Suomalaisugrilainen seura.

Tereshchenko, Nataliya 1990. Nenetski epos. Leningrad : Nauka.

Yuganpelik, Ivan 1987. Devushka Sikhirti. Severnoye Siyaniye. (Comp. \& ed. by I.F.Smol'nikov. Leningrad : "Prosveshcheniye".

\section{Recorded musical sources}

Nenyangg (Komarova), Lyubov' 1995b. Sawane' shyo. Recorded by L. Nenyangg, January 1995.

Susoi, Yelena 1988. Sikhirtya' ne nyu. Syoyotei Yamal - Pevuchi Yamal.

Melodiya S90 27639003 / B2.

Susoi, Yelena 1991. Sikhirtya' ne nyu. Recorded by J.Niemi, July 1991.

Nyarui, Semyon 198?. Wy yana" syo - "Song of the Tundra". Phonoarchive of the Yamal Nenets District radio, Salekhard (Ya-60).

Wennga, Al'bina 198?. "Pesni taimyrskikh nentsev". Phonoarchive of the

Taimyr Nenets District radio, Dudinka. 


\section{Interviews}

Susoi, Yelena 1991. Interview in Salekhard, Yamal Nenets Autonomous District, Russia. 27.3.1991. Interviewer: J. Niemi.

\section{Appendix 1}

Some preliminary results gained from the quantitative analysis of the line types according to their word combination.

1. Songs from the Malaya Zemlya (Western Nenets) in Kupriyanova's collection (Dobrovol'ski 1965, 766-780). These six fairly long songs represent the epic yarabtses $(89,43,73,35,21$ and 74 lines, respectively). (The line types are ordered here according to frequency of their occurrence.)

SS SSSS: $136 / 335: \quad 40.6 \%$

SS SS SS: $61 / 335: \quad 18.2 \%$

SSS SSS: $55 / 335: \quad 16.4 \%$

Two biggest line types: $\underline{58.8 \%}$ of all the lines.

SSSSSS: $32 / 335: \quad 9.6 \%$

Four biggest line types: $\underline{84.8 \%}$ of all the lines.

SSSS SS: $18 / 335: \quad 5.4 \%$

SS S SSS: $\quad 9 / 335: \quad 2.7 \%$

S S SS SS: $2 / 335: \quad 0.6 \%$

S S SSSS: $2 / 335: \quad 0.6 \%$

SS S SS S: $2 / 335: \quad 0.6 \%$

S SS SSS: $1 / 335: \quad 0.3 \%$

S SSSSS: $1 / 335$ : $\quad 0.3 \% \quad$ All six-syllable lines: $95.2 \%$ of all the lines.

Lines of the $2+2+2$-type altogether: $75.2 \%$ of all the lines. Lines of the $3+3$-type altogether: $20 \%$ of all the lines.

\begin{tabular}{llll} 
S SSSS: & $7 / 335:$ & $2.1 \%$ & The biggest types of the five-syllable lines: \\
SSS SS: & $4 / 335:$ & $1.2 \%$ & 78.6\% of all of the five-syllable lines. \\
\hline SSSSS: & $2 / 335:$ & $0.6 \%$ & \\
SSSS S: & $1 / 335:$ & $0.3 \%$ & All the five-syllable lines: $\underline{4.2 \%}$ of all of the \\
\hline SS SS: & $1 / 335:$ & $0.3 \%$ & lines. \\
SSS SSSS: $1 / 335:$ & $0.3 \%$ & All the other line types: $\underline{0.6 \%}$ of all of the lines.
\end{tabular}


2. Songs of A. H. Wèngga (Eastern Nenets) in the phonoarchive of the Radio of the Taimyr Nenets Autonomous District (Wèngga 198?). Wèngga's eight songs are shorter individual songs $(51,51,15,17,35,29,10$ and 11 lines respectively).

\begin{tabular}{lll} 
SSS SSS: & $66 / 219:$ & $30.14 \%$ \\
SS SSSS: & $56 / 219:$ & $25.57 \%$ \\
\hline SS SS SS: & $32 / 219:$ & $14.61 \%$ \\
SSSSSS(2+2+2): & $28 / 219:$ & $12.79 \%$ \\
\hline SSSS SS: & $10 / 219:$ & $4.56 \%$ \\
SS S SSS: & $5 / 219:$ & $2.28 \%$ \\
SSS SS S: & $4 / 219:$ & $1.83 \%$ \\
SSSSSS(3+3): & $2 / 219:$ & $0.91 \%$
\end{tabular}

Two biggest line types: $\underline{55.7 \%}$ of all the lines.

Four biggest line types: $\underline{83.1 \%}$ of all the lines.

All six-syllable lines: $\underline{92.7 \%}$ of all the lines.

The $2+2+2$-line type: $\underline{57.5 \%}$ of all the lines. The $3+3$-line type: $\underline{35.2 \%}$ of all the lines.

\begin{tabular}{llll} 
SSS SS: & $8 / 219:$ & $3.65 \%$ & \\
SS SSS: & $4 / 219:$ & $1.83 \%$ & The biggest types of the five-syllable \\
\hline S SSSS: & $1 / 219:$ & $0.46 \%$ & lines: $\underline{75 \%}$ of all of the five-syllable lines. \\
S SS SS: & $1 / 219:$ & $0.46 \%$ & \\
SS SS S: & $1 / 219:$ & $0.46 \%$ & \\
SS S SS: & $1 / 219:$ & $0.46 \%$ & $\begin{array}{l}\text { Other (five-syllable) line types: } \mathbf{7 . 3 \%} \text { of } \\
\end{array}$
\end{tabular}

\section{Appendix 2}

Sawanye's Song. Words and melody by Lyubov' Nenyangg (Nenyangg 1985, 19-22; 1989, 89-91; 1995a; 1995b). (Translation from Russian/Nenets to English: J. Niemi.)

Hajer" ninjanei, jaberyrngasei.

Numda njarakow, hobasjangasei.

Sjakwami sjamei, tshu"ui sjur(à)njam', jan' hamolangow, hajer" tolahow.

Ngapoi seiko(i)mei, tusj(à)da mjal(à)ha.

Wawmi hanjujei, tynei" jerw(à)sei".

Tshet(à) njamdèi jambèim', poder(y)ngadamtshei.

Noi pisotanam', hamedadamtshei.
Above me the sun

is shining.

The sky is perfectly

unclouded.

And my face

is so beautiful,

like the sun,

descended from the heights.

Only my heart

is like a hut without a fireplace.

My mattress is cold.

The reindeers have no master.

Four reindeers

I harnessed.

With a cloth blanket

I furnished the sledge. 
Hoi' sehèrèja', mjumnja hèringad(à)m', tshet(à) njamdèi jambèim', tjaha" harengad(à)m'.

Seimi lahoma, jimi pàroma, hanmi merenga.

Mertshja hynonga.

Hamantshei tynei", njand(à) mere"myjei? Njabi ngèsynèi, ngèwtortshj hèwènèi...

Mertsha nenzjamja. numda parima, hajer" jungguma, jimei tabtoma.

Wèwa tot(y)rewèi', hob(à)" purkobtatshe, nid(à)m' ngatshenanggu', nid(à)m' ngamdjoringgu'.

Tshebtèi jaljana nganei" toringgud(à)m', pulend(à)' hèwanèi pilei" ngamdangguw'.

Tèmd(à)' harenggudèi', mjat(à)' jesenggudèi', sit(à)' judanggudèi', njudad honggudèi'.

Sook(à)m' sèdanggud(à)m', pibid padtanggudm'.

ngapoi pydarir" si"limt(à)" mènenggudm'.
To the tundra-hill path

I set myself.

The four long-antlered ones

I spurred on.

My heart boiled with anxiety, my soul wanted to hurry, my sledge goes fast.

And the wind is singing.

Why my reindeers hurried to your place?

You already went to be married! to the neighbouring encampment...

The wind got angry, the sky turned black, the sun hid, I felt my soul pressed.

Like Yenko (Wèwa), leaning on the fur-hide,

I shall not wait,

I shall not sit.

Tomorrow

I (Sawane) shall come again, I shall come and sit beside you.

I shall drive your sledge, assemble the hut, I shall warm you, and give you children.

I shall sew you a coat, and also boots, only you

I shall love.

(Supplementary, filling lyrics with no definite meaning in connection with the text above:)

(Ngani" niw' nga" ngèi, nganei" manty(ni)wèi, nenèi hynonga, njàra hynonga.)
(Again, definitely, yes, again I am saying, a real human being is singing, your friend is singing.) 


\section{Appendix 3}

"Syihirtya-girl". ${ }^{14}$ By Yelena Grigor'yevna Susoi (1988).

Original transcription in Nenets and translation to Russian by Yelena Grigor'yevna

Susoi. Translation from Russian/Nenets to English by J. Niemi.

Saljow' (hohow(à))* jad(à)hanow (hèhèi) jad(à)hanow, On the slope of a hill (where the Syihirtya live), sihirtjow (hohow(à)) ne nju(ngèi) (hèhèi) ne nju(ngèi), a Syihirtya-girl

sjoridow wymd(à)nga(ngèi) (hèhèi) wymd(à)nga(ngèi), is sitting and weeping.

Sjamèi (hèhèi) jar(à)panei (hèhèi) jar(à)panei,

No matter how much I cried,

sihirtjow (hohow) nisjami(ngèi) (hèhèi) nisjami(ngèi),

tutow(y) sjanja(ngèi) (hèhèi) sjanja(ngèi),

my (Syihirtya)-father

is not coming back (from the war**).

Jangèi (hèhèi) howanow (hohow) howanow,

Somewhere on the foreign land,

sihirtjow (hohow) nisjani(ngèi) (hèhèi) nisjani(ngèi),

lyrei jeda jem(àn)dangow (hèhèi) (hè)jemdangow,

Hynggèi (hèhèi)r(à)ti(njàn)' saljow (hèhèi) saljow, jar(à)tow (hohow) tolaha(ngèi) (hèhèi) tolaha(ngèi), sjudatow(yn)' tolaha(ngèi) (hèhèi) tolaha(ngèi).

my Syihirtya-father's

bones probably have been bleaching in the wind already for a long time

(Also) the Hynggarte-hill**, sounds to be crying, sounds to be whistling.

*Susoi explains, that the additional words "hèhèi" and "hohow" symbolize other people (catching reindeers); sounds from the everyday life, somehow consoling the Syihirtya-girl (Susoi 1991).

**In the original poem of Ivan Yuganpelik (1987, 39-40), the Syihirtya-girl is orphan, whose "mother died of hunger and father was drowned in storming sea", and the girl is going to die soon in the chilling snow storm, but "it is her song, which, even after centuries, will be heard on the Hynggarta hill".

\section{Appendix 4}

Wy' yana" syo - "The song of the tundra" by S. N. Nyarui. Original text transcription in Nenets by Mariya Yakovlevna Barmich. Translation in Russian by Yelena Timofeyevna Pushkaryova. Translation from Russian/Nenets to English: J. Niemi.

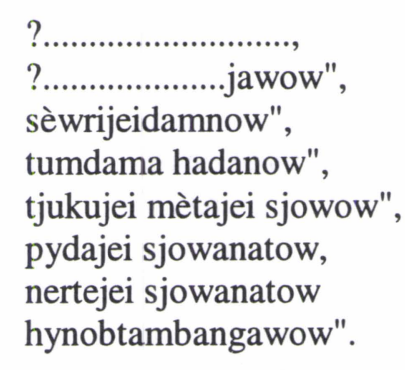$$
\text { ? }
$$
sèwrijeidamnow", tumdama hadanow", tjukujei mètajei sjowow", pydajei sjowanatow, nertejei sjowanatow
?.

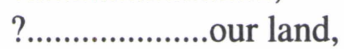

we are looking (our land), we learn to know our land, this is our song, the song of our land, it is her first song we are singing.

${ }^{14}$ The Syihirtya are ancient small people in the Nenets mythology, who are believed to have lived in the Northern tundra, before the Nenets came to the North. This belief has probably some connection with the fact that the Northern Eurasia was populated by some unknown ethnic groups before the Samoyed-speaking peoples came to the North (cf. Khomich 1966, 29; 31). 


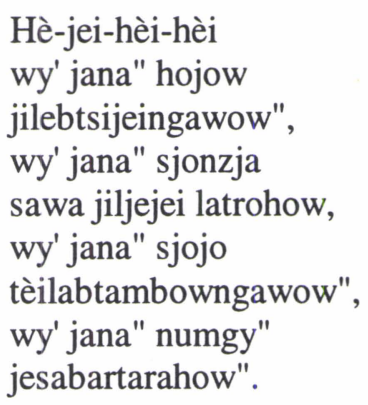

Sèwèinanow jadèjei ngarka wy' jawow", harjoi nganamda jilaribèinandow" tirtjàjei sarmeikètsèjei munyjei tèlabirngow", (o-)horekodarewèi telèwèkoraha.

Hè-jei-hèi-hèi...

Mertsjajei wysyl(à)mèjejei sjo hanabanow", ja sarpei mjunjow ngèdaljobèinanow", wyngèjei sehèrèmèi mjudngow" njodalbatow", jireinanèj sjojow har"na wètabiwow".

Hè-jei-hèi-hèi...

Har"najei wynggèi jawow hyno"langawow", har"na pèrtjawow sawaliseitywow". Partijana" neda pilejei njodangadow", jalèimdadèi numgyjei ngudondonengadow".

Hè-jei-hèi-hèi...
Hè-jei-hèi-hèi

we are living

on our tundra, it is good to live on our tundra, we are spreading around the songs of our tundra, the stars of our tundra are twinkling everywhere.

Look

at our vast land;

if the aeroplanes

are climbing to the skies

the warble of the birds

overcomes them, the reindeer calves are echoing them.

Hè-jei-hèi-hèi...

The winds are storming, when we sing our songs, when we are travelling along the tundra paths, when our slegde-caravans are on the move along the tundra roads, we continue to compose ourselves the songs of our forefathers.

Hè-jei-hèi-hèi...

We are singing about our tundra, we are praising our deeds. We are following constantly the path of our Party, the morning star is guiding us.

Hè-jei-hèi-hèi... 